\title{
Kapadokyalı Rumların Aydınlanma Çabasına Anatoli Gazetesi Üzerinden Bakmak
}

\begin{abstract}
Kapadokyalı Rumların Aydınlanma Çabasına Anatoli Gazetesi Üzerinden Bakmak

Öz

Bu makale çoğunun anadili Türkçe olan Kapadokya Rumlarının aydınlanma çabalarına odaklanmaktadır. Bu cemaat, bazı akademik kaynaklarda Karamanlılar veya Anadolu Hıristiyanları olarak da nitelendirilmektedir. Anadolu Hıristiyanları ondokuzuncu yüzyılda büyük liman şehirlerine göç etmeye başlamışlar ve akabinde de memlekette kalan hemşehrilenin eğitim yoluyla aydınlanmasına yönelik bir hareket başlatmışlardır. Elinizdeki makale, bu süreci Anatoli gazetesinin 1891-1899 yılları arasında yayınlanan nüshaları üzerinden incelemektedir. Anatoli gazetesi Yunan harfleri ile Türkçe olarak basılmış, yayın hayatına 1851-1912 yılları arasında devam etmiş ve Anadolu Ortodokslarının aydınlanma ve ahlaki değerlerini koruma çabalarına destek vermiştir.
\end{abstract}

Anahtar Kelimeler: Kapadokya, Anadolu Rumları, Aydınlanma, Karamanlılar
A Glimpse inside Cappadocian Orthodox's Endeavor of Enlightenment Through the Pages of Anatoli Newspaper

\section{Abstract}

This article focuses on enlightenment endeavors of the Cappadocian Orthodox most of whom had Turkish as their mother tongue. The community at hand is also recorded either as Karamanlides or as Anatolian Christians in some academic literature. Anatolian Christians faced the phenomenon of migration towards big port cities in the nineteenth century and afterwards they initiated a movement of enlightenment of those who remained in homelands through education. This article analyzes this process through the issues of Anatoli newspaper which were published between 1891 and 1899. Anatoli was published in Turkish with Greek letters, remained in circulation between 1851 and 1912; and supported the enlightenment of Anatolian Orthodox as well as protection of their moral values.

Keywords: Cappadocia, Anatolian Orthodox, Enlightenment, Karamanlides

\section{Giriş}

Türkiye'nin kültür tarihine bakarken konuyu çoğunlukla Osmanlı'dan günümüze olarak ele alırız ancak sıklıkla Osmanlı coğrafyasının çok halklı, çok kültürlü yapısını göz ardı ederiz. Bu çalışmayla hedeflenen, bu göz ardı edilmişliğe karşılık olarak, Türk-Yunan Nüfus Mübadelesi (1923) öncesinde Anadolu'daki sayıları elli bin ${ }^{2}$ civarında gösterilen Kapadokya Rumlarının ondokuzuncu yüzyılda bir uyanış hatta bir aydınlanma yaşadıklarını, göç olgusu, hemşehri (kardeşlik) cemiyetleri, mektepler ve mektepler yararına düzenlenen etkinlikler üzerinden göstermektir. Makalenin dayandığı birincil kaynak, ondokuzuncu yüzyılın ikinci yarısında yayın hayatına başlayan Anatoli gazetesinin 1891 ve 1899 yılları arasında basılmış nüshaları olacaktır. Anatoli gazetesine ve onun özelde Kapadokyalılar, genel olarak da Rum Cemaati için anlamına gelmeden önce makalede kullanılan bazı terimler açıklanacaktır.

Öncelikle Rum sözcüğünü açıklamak doğru olacaktır. Rum sözcüğü, Romalı anlamına gelen Yunanca Romios kelimesinden türemiştir. Burada kastedilen Romalı, elbette, Doğu Roma İmparatorluğu, yani Bizans'tır. Bizans ülkesinin çoğunluğu Ortodoks kilisesine mensup ahalisi, etnik

\footnotetext{
${ }^{1}$ Öğr. Gör., Eskişehir Osmangazi Üniversitesi, iiBF, Siyaset Bilimi ve Kamu Yönetimi Bölümü, gulen.gokturk@gmail.com

2 Yunanistan'da 1928'de yapılan nüfus sayımına göre Yunanistan'da 103.642 Türk dilli Rum bulunmaktadır. Bunların 50.000 kadarı Kapadokya, Doğu Karadeniz ve Küçük Asya'nın diğer bölgelerinden gelmişlerdir. Bkz. Harakopoulos, Maximos, (2014).
} 
kökenleri ne olursa olsun Romalı olarak kabul edilmiştir. Bizans'ın kalbindeki Anadolu yarımadası da o dönemde, hatta Türk egemenliğine girdikleri dönemde dahi Rum (diyar-ı Rum) olarak adlandırılmıştır. Osmanlılar döneminde ise Rum kelimesi Ortodoks Hıristiyan ahaliyi tanımlamak üzere ve kesinlikle etnik bir grubu işaret etmeksizin kullanılmıştır. Sırp Ortodoks da, Bulgar Ortodoks da, anadili Yunanca olan İstanbullu bir Ortodoks da ve hatta anadili Türkçe olan Anadolu Ortodoksu da Rum cemaatinin bir parçasıdır. Ülkemizde cumhuriyetin ilanından sonra Osmanlı geleneği devam etmiştir ancak bu sefer bir fark göze çarpmaktadır. Etnik olarak Yunan olan ve Fener Rum Patrikhanesine bağlı olan azınlık grubu Rum olarak nitelendirilmeye devam etmiştir. Konuştukları dile de Yunanca değil Rumca denmiştir. Buna karşılık, aynı etnik kökene sahip olan ve aynı dili konuşan Yunanistan vatandaşları Yunan olarak nitelendirilmişlerdir, dilleri ise Yunanca olarak adlandırılmıştır. Helen kelimesi dilimizde kabul görmezken, Arapça İyon kelimesinden türeyen Yunan kelimesi benimsenmiştir.

Osmanlı İmparatorluğu'nun Anadolu Rumları, yani Anadolu içlerinde yaşayanlar, özellikle de Kapadokyalı olanlar "Karamanlılar" olarak da anılırlardı. Karamanlılar hakkında son zamanlarda gelişen geniş bir literatür vardır. Karamanlılara ait literatürünün bir kısmının başını Kapadokya kökenli Yunan tarihçi Evangelia Balta'nın çektiğini söyleyebiliriz. Yazdığı kitap, makale ve düzenlediği uluslararası çalıştaylarda tarihçi, "Karamanlılar" üzerine bir köken tahlili yapmamaktadır. Bir başka değişle, Karamanlılar kökende etnik olarak Yunan mıdır yoksa Türk müdür sorusunu kaynak yetersizliği nedeniyle cevaplamaya çalışmamaktadır. Onun yerine, onların yazıp çizdiklerine, çıkardıkları gazete ve dergilere odaklanır ve onların ağzından "Karamanlılar kimdir" sorusuna cevap vermeye çalışır. Örneğin yazar, Kaisareia Metropolitleri (1896) adlı kitapta aşağıdaki tanımlamaya rastlamış ve aktarmıştır:

“Gerçi Rum isek de Rumca bilmez Türkçe söyleriz. Ne Türkçe yazar okur, ne Rumca söyleriz. Öyle bir mahludi hattı tarikatımız vardır. Hurufumuz Yonaniçe, Türkçe meram eyleriz" (Balta, 2013:25).

"Siz kimsiniz" sorusunun belki de en yalın cevabı olan bu tanımla Karamanlıları dert edinen yayınların çoğunda karşılaşırız. Rum Ortodoks kilisesi mensubu olan Karamanlılar, Türkçe'yi Yunan alfabesiyle yazmış (bu dile Karamanlıca adı verilir); çeşme kitabelerinden, kilise yazıtlarına, mezar taşlarına hatta kimi bölgelerde dualarına varana kadar Türkçe kullanmışlardır. Çoğunluğu Osmanlı Devleti'nin sonradan Konya vilayeti olan Karaman eyaletine bağlı şehir ve köylerde yaşayan bu insanlara Karamanlı denmesinin nedeni olumsuz anlamda "farklı" olarak algılanmalarından kaynaklanmıştır. Bu sıfat, büyük şehirlerde özellikle Yunanca konuşan dindaşları tarafından onları aşağılamak ve "köylü", "kara" olarak nitelendirmek üzere kullanılmıştır (Benlisoy vd., 2010). Halbuki onlar, Anadolu'da yaşadıkları yıllarda Karamanlılar betimlemesini asla kullanmamış ve kabul etmemişlerdir. Çıkardıkları yayınlarda kendilerini bazen Anadolu Hıristiyanı olarak, bazen salt Anadolulu olarak, bazen de kendilerini Protestan ve Katolik misyonerlerden ayırmak için Anadolu'nun Rum Ortodoks Hıristiyanları olarak tanıtmışlardır (Clogg, 1996; Balta, 2003; Benlisoy vd., 2010; Göktürk, 2015). Kendilerinden bahsederken vurgu çoğunlukla yaşadıkları coğrafyaya ve sılaya işaret etmiştir. Elbette bu durum, ondokuzuncu yüzyılda ortaya çıkan milliyetçilik akımı nedeniyle zaman içinde farklı bir boyuta geçmiştir. Anadolu Hıristiyanlarının bir kısmı Yunan kimliğini benimsemiştir. Hatta çocuklarına Eski Ahit'te geçen veya Türkçe olan geleneksel Kapadokya isimleri yerine, Yunan isimleri, hatta etnisite vurgusu yapmak için pagan dönem Yunan isimleri verdikleri bilinmektedir. Fakat bu durum genellenemez. Örneğin, bazı Anadolu Rumları milliyetçilik akımlarına kayıtsız kalmış ve Türk-Yunan Savaşı'nda (Kurtuluş Sa- 
vaşı, 1919-1922) dahi tarafsız bir duruş sergilemişlerdir. Hatta Papa Eftim adlı bir papaz, Anadolu Hıristiyanlarının Türk olduğuna dair bir propaganda hareketine girişmiş, dönemin Ankara hükümeti tarafından desteklenmiş ve bugün Karaköy'deki Türk Ortodoks Patrikhanesi'nin temelleri savaş yıllarında Kayseri'de atılmıştır (bkz. Benlisoy, 2016; Ergene, 1951). Bu bilgiler ışığında makalede Kapadokya Rumları, Kapadokya Hıristiyanları, Anadolu Rumları, Anadolu Hıristiyanları ve Anadolu Ortodoksları gibi terimler dönüşümlü olarak kullanılacaktır.

Karamanlılar literatürünün bir tarafında da köken tartışması yapan çalışmalar vardır. Hem Türkiye'de, hem de Yunanistan'da milliyetçi tarihyazımı onları etnik olarak Yunan veya Türk olarak resmetmektedir. Yunan bakış açısı onları, Türk "tahakkümünden” ötürü dilde Türkleşmiş Yunanlar olarak göstermektedir (Vryonis, 1971; Alexandris, 1999); Türk bakış açısı ise onları Bizans ordusunda paralı askerlik yapmış etnik Türkler olarak ele almakta ve o dönemde dinde Hıristiyanlaştıklarını iddia etmektedir (Baykurt, 2007; Ergene, 1951; Ekincikli, 1998; Anzerlioğlu, 2009). Bu görüşler kaynak eksikliğinden dolayı tarihi dayanaktan yoksundur. Öte yandan, Anadolu coğrafyasının tamamında Rumların daha ziyade Türk dilli olduklarını da unutmamak gerekmektedir. Yunan tarihçi Sia Anagnostopoulou (2013), “izmir'in etrafından bir yay çizersek, Anadolu'da yayın bombeli kısmının arkasında kalan bölgelerin çoğunda Rum ahalisinin Türkçe konuştuklarını" yazmıştır. İlginç bir nokta daha bulunmaktadır. Kapadokya'da ondokuzuncu yüzyılın sonunda dahi Kapadokya Yunancası konuşulan yerleşim birimleri mevcuttur. Özellikle Niğde'nin, Nevşehir'in ve Konya'nın köy ve kasabalarında Yunanca konuşulmaktadır. Ancak aynı yörenin kent merkezlerinde Rumların konuştukları dil Türkçe'dir. Kayseri'de ise neredeyse tüm Rum ahali Türkçe konuşmaktadır (Göktürk, 2015). Buna ek olarak, bölge yüzyıl boyunca göç verdiği için, aslen Yunanca konuştuğu halde, Türk çoğunluğun içerisinde giderek sayıca azalan Rumların bazı bölgelerde Yunanca yerine Türkçe konuşmaya başladıkları da gözlemlenmiştir(Dawkins, 1916).

Kısacası, köken tartışması yapmak için fazlasıyla karmaşık bir durumla karşı karşıya olduğumuzu söyleyebiliriz. Hatta, yukarıda ifade edildiği gibi, bu makalede "Karamanlılar" kelimesi kullanılmamaktadır. Zira Türk dilli olsunlar ya da olmasınlar Anadolu Rumları, bir başka değişle Kapadokya Rumları, aşağılayıcı buldukları için Osmanlı ülkesinin vatandaşları oldukları dönemde bu adlandırmayı kendi kaynaklarında hiçbir zaman kullanmamışlardır. Karamanlılar demek onlara bağlı bulundukları Rum cemaatinin içerisinde ayrı bir grup gibi muamele etmek anlamına gelecektir. Bu çalışmada cemaat içinde cemaat yaratmak gibi bir tutum benimsenmemektedir. Fakat yine de belirtmek gerekir ki, bugün Yunanistan'da pek çok Anadolu kökenli Yunan kendilerine Karamanlılar denmesine tepki göstermemekte hatta bu terimi sosyal medya platformlarında kullanmaktadırlar.

Bu çalışma açısından açıklığa kavuşturulması gereken unsurlardan biri de "Kapadokya" ile aşağı yukarı hangi bölgelerin kastedildiğidir. Kapadokya bölgesinin sınırları tarih boyunca her dönemde farklı şekillerde gösterilmiştir. Bu çalışmada ondokuzuncu yüzyılda Rumların Anadolu'daki varlığı ölçüsünde bir tanım yapılmakta ve bugünden farklı olarak daha geniş bir coğrafya Kapadokya olarak ele alınmaktadır. Bu da Evangelia Balta'nın Kapadokya tanımına denk düşmektedir. Balta'ya göre Kapadokya bölgesini kuzeyde Ankara, Yozgat ve Hüdavendigar; güneyde Adana ve Antalya; batıda Aydın vilayeti ve doğuda Kayseri ve Sivas sınırlamaktadır (Balta, 2003). Yani bugün anladığımız anlamda, turistik bir bölge olan Nevşehir'deki Kapadokya kastedilmemektedir. 
Son olarak, bu makalede 1851 yılında Evangelinos Misailidis tarafından çıkartılmaya başlanan Anatoli gazetesinin 1891-1899 yılları arasındaki nüshaları ${ }^{3}$ üzerinden göç, göçün gidenler ve kalanlar üzerindeki etkileri, gurbette kurulan cemiyetler, cemiyetlerin memleketle kurdukları bağ, sılada desteklenen mektepler, mekteplere bağış toplamak üzere İstanbul'da düzenlenen parastasiler (gösteri, temsil), ve bu etkinliklerde karşılaşılan durumlar ele alınacaktır. Başka bir deyişle, Kapadokya'dan İstanbul'a göçmüş Rum cemaatinin İstanbul'daki kültürel etkinliklerine ve eğitime verdikleri öneme değinilecektir ve tüm bunlar ışığında Anadolu Rumlarının bir çeşit "aydınlanma" yaşayıp yaşamadıkları tartışılacaktır.

\section{Kapadokya'dan Göç ve Hemşehri Cemiyetleri}

Ondokuzuncu yüzyılda Osmanlı coğrafyasını dönüştüren sosyal ve ekonomik gelişme ve değişimler Rumları da etkilemiştir. Bu dönemde Kapadokya bölgesinden İstanbul, İzmir, İskenderiye, Kahire, Mersin gibi ticaret ve liman kentlerine ve hatta Odesa ve Amerika'ya göçler başlamıştır. Önceleri bu göçler, sadece evin erkeğinin para kazanmak amacıyla memleketini terk etmesi olarak ortaya çıkarken, yüzyıl sonuna doğru ailecek göçler de görülmüştür. Göçle büyük şehirlere giden Kapadokya Rumları gittikleri yerlerin Rumca konuşan Rum Ortodoks ahalisi tarafından zaman zaman dışlanmış hatta aşağılanmışlardır. Bu yüzden göçün giden erkekler üzerinde bir kimlik bunalımı yarattığını söylemek abartılı bir görüş olmayacaktır (Augustinos, 1997). Dışlanmış olmaktan ötürü bir dayanışma oluşturmak için hemşehrileriyle bir araya gelerek ve sılaya yardım etmek amacıyla dernekler ve hemşehri (kardeşlik) cemiyetleri kurmuşlardır. Bu kuruluşların oluşmasında elbette Yunan milliyetçiliğinin etkisinde İstanbul ve Atina'da kurulan syllogos adı verilen, eğitim, aydınlanma ve Anadolu Rumlarını örtük olarak Helenleştirme amaçları güden derneklere duyulan saygı ve özentinin de etkisi olduğunu söylemek mümkündür. Bu dernekler, eğitim için Yunanistan Krallığı'ndan öğretmenler getirtmiş, tarihten arkeolojiye, sağlıktan pozitif bilimlere ve hijyen kurallarına uzanan geniş yelpazedeki konularda konferanslar düzenlemiş ve Osmanlı Devlet yetkililerinin dikkatlerini çekmemek için örtük bir biçimde Yunan olma bilinci aşılamışlardır. ${ }^{4}$

Yukarıda belirtildiği gibi, Anadolu Rumlarının hemşehri cemiyetleri syllogos hareketinden etkilenmiştir. İstanbul'da yaşayan Nevşehirli Ortodokslar tarafından kurulan Papa Yeorgios nam Cemiyet-i İslahiyyesi (1911) bunlardan biridir. Bu tip derneklerin başlıca amaçlarından biri geldikleri yerlerde eğitim olanaklarının sağlanmasıdır. Eğitimin hedeflerinden biri de Türkçe konuşan çocuklara Yunanca öğretilmesidir (Benlisoy, 2003). Öncesinde de Kapadokya'daki Hıristiyan yerleşkelerinde eğitim verilirdi ancak bu eğitim çoğunlukla köyün papazı veya zengin ailelerin çocukları için tuttukları özel öğretmenler tarafından gerçekleştirilirdi. Rumca eğitimi ise neredeyse yoktu. Çocuklar Rumca ile dini metinler dışında bir bağ kurmakta zorlanırlardı. Yine de cemiyetlerin desteklediği okulların tamamen sevinçle karşılandığını söylemek zordur. Örneğin Gelveri'de (Aksaray-Güzelyurt) 1850'de kurulan modern okula kalabalık bir grubun, "okulda dinsizliğin ve ahlaksızlığın öğretileceği" zannıyla taşlı sopalı bir saldırı gerçekleştirdiklerini Stefo ve Foti Benlisoy bize aktarmaktadır (2000: 25). Bir başka tepki de okullarda öğretilen Yunanca diline karşı yükselmektedir. Yine Benlisoy kardeşlere göre Papa Yeorgios cemiyeti tarafından çıkarılan 1913 yıllığında Yunanca değil, Türkçe kullanılması şöyle savunulmuştur:

"Hemşehrilerimizin bazıları Anadolu dilini (Türkçe) terk etmemiz ve bu salnameyi Yu-

nanca yayımlamamızı tavsiye ediyor. Onlara şu soruyla cevap veriyoruz: Yunanca'yı

\footnotetext{
${ }^{3}$ Söz konusu nüshalara Ankara'daki Milli Kütüphane'den erişilebilir.

${ }^{4}$ Syllogos hareketi için bkz., Vassiadis, George, (2007).
} 
yeterince bilenler yüzde kaçtır? Bu türden bir eseri anlamak içinse iyi Yunanca bilmek gerekir. Vakiyle okullarımızda Yunanca öğrenmiş olanların hangisinin aklındadır bunlar?" (Benlisoy, vd., 2000).

Bu tepkiler milliyetçi bir okumaya maruz bırakılabilir ancak bu doğru bir yaklaşım olmayacaktır. Birinci örnek daha ziyade gelenekselin yeni olana tepkisi gibi algılanmalıdır. İkinci örnekte ise karşı çıkılan Yunanca'nın kendisi değildir. Sadece Türkçe olarak çıkarılan salnamenin Hıristiyan ahaliye daha rahat ulaştırılabileceği iddia edilmektedir. Bir başka örnek de Anatoli gazetesinden verilebilir. Hem tavsiye, hem rica başlığıyla Yannis Gavriilidis tarafından yazılan yazıda şöyle denilmektedir:

“Nevşehirliler'in mektepler uğrunda ne kadar fedakarlıklar gösterdiklerini izah etmek abestir. Zira her gün nazar-ı memnuniyet ile görülüyor...Umum-u Anadolu'da Kayseriye'nin mekteb-i kebiri ${ }^{5}$ bir tarafa bırakılırsa, Nevşehir mektepleri gibi muntazam mektep yoktur. Lakin bir eksiği vardır. $\mathrm{O}$ da Türkçe lisana ehemmiyet vermemeleridir...Biz teba-ı şahaneden ve ez cümle alış-veriş içerisinde bulunuyoruz. Ba-husus ahzu itamızın yüzde doksan dokuzu Türkçe'dir. Niçin yazıp okumayalım?...Mekteplerde çocuklara Astronomia (astronomi) veyahud theologia (ilahiyat) okutmaktan ise lisanI Türki'yi layıkıyla belletmek daha evliyadır."6

Gelen tepkilere cevap vermek için Gavriilidis, gazetenin bir sonraki sayısında şöyle der:

"Almış olduğum malumata göre halisane olarak ettiğim şu rica bir takım hemşehrilerimiz indinde memnuniyetle telakki olunmayıp, başka başka manalar veriliyor imiş...Varakamda Nevşehirliler'in mektepler hususunda ne kadar semahatı bulunduklarını...taadat eyledikten sonra yalnız lisan-ı Türki'ye ehemmiyet vermediklerini arz eylemiş idim. Halbuki bendeniz(in) bu fikri ekserilir(?) nezdinde Türkçe hiç bilmezler manasına tevsir olunmuş."

Gavriilidis okullarda Türkçe de öğretilmeli demektedir, bir kısım Nevşehirli de "sen bize Türkçe bilmez mi demek istiyorsun?" diye tepki göstermektedir. Ahalinin tepkisi Türkçe'nin okullarda okutulması fikrine değildir; Gavriilidis'in uyarısını yanlış anlamış görünmektedirler. Kısacası Nevşehirliler'in anadilleri olan Türkçe'ye olan bağlılığı okullarda Yunanca'nın öğretilmeye başlaması ile azalmamaktadır.

Derneklerden söz etmişken nizamnamelerinden örnek vermek yerinde olacaktır. Örneğin Aksaray Gelveri'nin (Güzelyurt) İstanbul'da kurulmuş olan Nazianzos derneğinin amaçları 1884 senesindeki nizamnamesinde aşağıdaki gibi belirtilmiştir:

a) Gelveri karyesinin Rum mekteplerinin anaokulu, kız okulu ve astiki (kent) okulunun terakki ettirilmesinden;

b) fakir talebelere kitap ve kırtasiye malzemesi temininden sorumludur. ${ }^{8}$

Yine Niğde'nin Aravan (Kumluca) köyünden İstanbul'a göç edenler tarafından 1905'te kurulan Agios Yorgos cemiyetinin kurucu amaçları nizamnamesinde şöyle belirtilmiştir:

a) Aravan okulunu desteklemek ve bütçe açı̆̆ını kapatmak;

b) sulama sorunları olan köyün kanallarını düzenli olarak tetkik etmek;

\footnotetext{
${ }^{5}$ Zincidere kariyesindeki ruhban okulu kastedilmektedir.

${ }^{6}$ Anatoli, 24 Ocak 1891: 4288.

${ }^{7}$ Anatoli, 29 Ocak 1891: 4290.

${ }^{8}$ Der-i Saadette vaki Gelveri'nin Maarifperver Nazianzos Nam Uhuvetinin Nizamnamesi Tesisi, 1884. Nizamname Atina'daki Küçük Asya Araştırmaları Merkezi'nden temin edilmiştir.
} 
c) yılın belirli zamanlarında köyün fakirlerine yardım etmek. ${ }^{9}$

Buraya kadar Karamanlıların kim olduklarından, imparatorluğun değişen koşulları içinde göç etmelerinden, göç ettikten sonra sılaya yardım için büyük şehirlerde kurdukları hemşehri cemiyetlerinden ve bu cemiyetlerin amaçlarından bahsedilmiştir. Bundan sonraki başlık altında tartışmaya biraz da İstanbul'a göç eden Kapadokyalıların kurduğu hemşehri cemiyetlerinin memleketlerinde destekledikleri okullara yardım için tertip ettikleri etkinliklerin Anatoli gazetesinde yer bulması üzerinden değinilecektir.

\section{Evangelinos Misailidis ve Anatoli (Şark) Gazetesi}

Manisa Kulalı Evangelinos Misailidis Efendi (1820-1890) Rum cemaati için çok önemli bir isimdir. Kendisinin kurucusu olduğu Anatoli yani Şark gazetesi ölümünden bir yıl sonra onu "Anadolu Hocası" olarak tanımlamıştır. ${ }^{10}$ Sahibi olduğu matbaada doksan iki adet Karamanlıca yani Yunan harfli Türkçe eser basmıştır. Bu rakam toplam Karamanlıca kitap üretiminin yüzde otuzuna denk düşmektedir (Balta, 2003; Erol, 2004). Kendisi ayrıca romancı kimliği ile de bilinmektedir. Yazmış olduğu "Temaşa-i Dünya ve Cefakar-u Cefakeş" adlı romanı Türkçe olarak kaleme alınmış ilk romanlardandır. Kitap 1872'de dört cilt halinde basılmıştır. Bu tarih, hepimizin ilk Türkçe romanlar olarak bildiği Ahmet Midhat Efendi'nin $1875^{\prime}$ de basılan Hasan Mellah ve Hüseyin Fellah romanlarının öncesine denk düşmektedir. Evangelinos Misailidis yazdıkları ve yayınladıklarıyla cehalette gördüğü Anadolulu Rum dindaşlarını aydınlatmaya çalışmıştır. Yine bu amaçla kurduğu ve yayın hayatına 1843'te İzmir'de başlayan ve 1851'den itibaren İstanbul'da devam eden Anatoli (Şark) gazetesi, bazı tarihçilere göre 1912, bazılarına göre ise 1922'de yayın hayatına veda etmiştir (Tarinas, 2007).

Anatoli gazetesinde, başlığın hemen altında şöyle bir tanıtım notu bulunmaktadır: "Siyasiye, Fenniye, Tüccariye ve havadis-i mütenevviadan bahis gazete. Şimdilik haftada üç defa salı, perşembe ve cumartesi çıkar." İçerik nüshadan nüshaya farklılıklar gösterse de belli başlı konulara hep değinilmiştir. Bunlar kilise bilgilerinin yer aldığı ekklisiastika, borsa, imerologion (tarihte bugün olarak çevirebiliriz ancak azizler ve Ortodoks dini hakkında bilgiler içermektedir), dahiliye ve/veya tilegraf (telegraf, Osmanlı coğrafyasından ve dünyadan haberler), tefrika (çoğunlukla Osmanlıca'dan Karamanlıca'ya çevrilmiş hikayeler) ve theatron (tiyatro ve etkinlik duyuruları) olarak sıralanabilir. Yine her sayının arka sayfasında reklamlar bulunmaktadır. Bunlar İstanbul'da bir mağazaya veya uluslararası bir markaya ait olabilir.

1890 yılı itibariyle gazetenin abone sayısı beş yüzdür; 1895 'te ise bu sayı üç yüze inmiştir. ${ }^{11}$ Bu tiraj her ne kadar az gibi görünse de gazetenin en çok satan Karamanlıca gazete olduğu ve sadece İstanbul ve Kapadokya'da değil, Adana, Şebinkarahisar, Bafra, Ünye, Samsun ve Adapazarı'nda dahi abonelerinin olduğu gerçeğini değiştirmemektedir (Şimşek, 2010). Gazete çok satıyor gibi görünmese de çok okunmuştur. Bu durum, gazetenin 1892-1898 yılları arasındaki başyazarı Yannis Kalfoğlu'nun “Anadolu neden terakki etmiyor?” yazısında bahsettiği ve kınadığı "otlakçılardan" kaynaklanmıştır. Abonelik borçları ödenmediği gibi, bir de tek bir gazete nüshası elden ele dolaştırılmıştır. ${ }^{12}$

\footnotetext{
9 Agios Yorgos: Aravan Kariyesi'nin İstanbul'daki Kardeşlik Cemiyeti, 1905. Atina'daki Küçük Asya Araştırmaları Merkezi'nden temin edilmiştir.

${ }^{10}$ Anatoli, "Hemşehrilerimize", 7 Şubat 1891: 4293,

${ }^{11}$ N. T. Soullidis, "Hemşerilerimize”, Anatoli, 11 Aralık 1890: 4271 ; N. T. Soullidis, "Anatoli Gazetesi Ser Muharriri Rıfatlı loannis Kalfaoglou Efendi'ye", Anatoli, 5 Aralık 1895: 5173.

${ }^{12}$ Anatoli, “Anatoli Neden Terakki Etmiyor?”, 4 Aralık 1895: 5172.
} 
Şekil 1: Anatoli gazetesinin 5 Şubat 1891 tarihli ve 4292 numaralı nüshasının kapağında bir sene önce vefat etmiş merhum Evangelinos Misailidis Efendi'nin fotoğrafı bulunuyor.

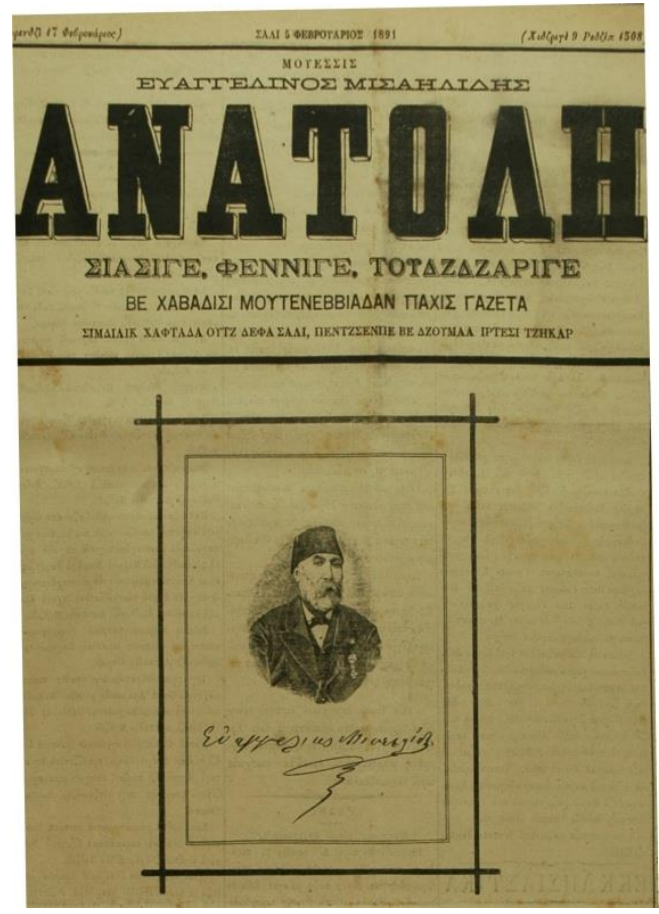

Kaynak: Fotoğraf, Gülen Göktürk

Anatoli, eğitime ve Anadolu'nu aydınlanmasına ilk yayına çıktığı 1851'den beri büyük önem vermiştir. Bir taraftan da misyonerlik faaliyetlerine karşı Ortodoks Hıristiyanlığın sözcüsü gibi davranmıştır. ${ }^{13}$ Örneğin, "Ortodoksia'nın muhafazası" adlı bir makalede Protestan misyonerlerinin çabalarını boşa çıkartmak için Ortodoks kilisesinin ne gibi önlemler alması gerektiği tek tek açıklanmıştır. Buna göre, Ortodoks papazları "Pazar dersleri" yapmalı, mitropolitler iki ya da üç vaiz işe almalı, cahil insanlar artık papaz yapılmamalı ve yeterli bilgisi olan öğretmenler din dersleri vermelilerdir. ${ }^{14}$ Tüm bunların yanında Rum Ortodoks Kilisesini çoğu Anadolu Hıristiyanının anadili Türkçe iken, inatla sadece Yunanca yayın yapmaması gerektiği konusunda uyarmıştır. ${ }^{15}$ Ayrıca Yunan alfabesiyle Türkçe yazım kurallarının oluşturulmasında bir referans kaynağı haline gelmiş ve yazı dilinin ağdalı Osmanlı Türkçesi'nden Anadolu Türkçe'sine sadeleştirilmesinde önemli bir rol oynamıştır.

Anatoli gazetesinin, eğitim ve dolayısıyla aydınlanmayı her daim desteklediği anlaşılmaktadır. Aydınlanmayı, yalnızca dönemsel gelişmeler, hijyen, bilim, davranış, akrabalık ilişkileri, nezaket kuralları vb. konular ile ilgili makaleler yayınlayarak değil, aynı zamanda Kapadokya ve diğer Anadolu hemşehri cemiyetlerinin, sıladaki mektepler yararına İstanbul'da tertip etmiş oldukları gösterileri ilan ederek ve davetiyelerini yayınlayarak da desteklemiştir. Gazetenin theatron kısmında bu etkinliklerin duyuruları yer almış, daha sonraki baskılarının dahiliye kısmında

\footnotetext{
${ }^{13}$ A. Grigoriadis, “Anatoli'nin Devamına Lüzum Var mı Yok mu?”, Anatoli, 8 Aralık 1895: 5175.

${ }^{14}$ Anatoli, “Orthodoksia'nın Muhafazası", 12-14 Şubat 1894: 4773-4774.

${ }^{15}$ I. Sadeoglou, "Izhar-ı hissiyat", Anatoli, 26 Şubat 1896: 5235.
} 
ise etkinliğin nasıl geçtiğine dair notlara yer verilmiştir. Aşağıda birkaç tanesi örneklendirilmektedir:

"Niğde'ye muzaf Aravan kariyesi Sholionu (okulu) menfaatine olarak, mah-i halin 27'nci Pazar günü akşamı Şehzade pazarında direkler arasında vaki Osmanlı Tiyatrosu'nda Minakyan Efendi Maarifeti ile Paris'te Misk Sokağı Vakası nam yedi perde drama ve bir perde komodia (komedi) icra olunacağından, vatan ve ilimperver hemşehrilerimizin teşrife rağbet buyurmaları siyakında ilim, mekteb ve medeniyetin terakkisine her vakit için fedakarlığı ibraz eden muteber gazeteniz(de) ilan buyurmanız ve zirinde mutala-i alilenizin ilavesi rica olunur efendim."16

"Konya vilayeti dahilinde Niğde Kurdonos (Hamamlı) kariyesinin Rum mektepleri menfaatine olarak gelecek Pazar gübü (17 Fevruarios) Beyoğlu'nda Tepe Başı Bahçesi Theatrosunda (tiyatrosunda) akşam üstü yani Pazartesi gecesi saat iki buçukta başlayarak Türkçe lisanında "Talihsiz Kadın" nam drama ile "Balıkçı Apti” nam komodia (komedi) ve iki kanto ile operalı bir baleto (bale) tasvir ve icra olunacaktır."17

Şekil 2: Yukarıda bahsi geçen Aravan Rum okulunun tabelası. Üzerinde "Aravan kariyesi okulu, cemiyetimizin şerefli yardımlarıyla inşa edilmiştir. 1 Mayıs 1891" yazıyor.

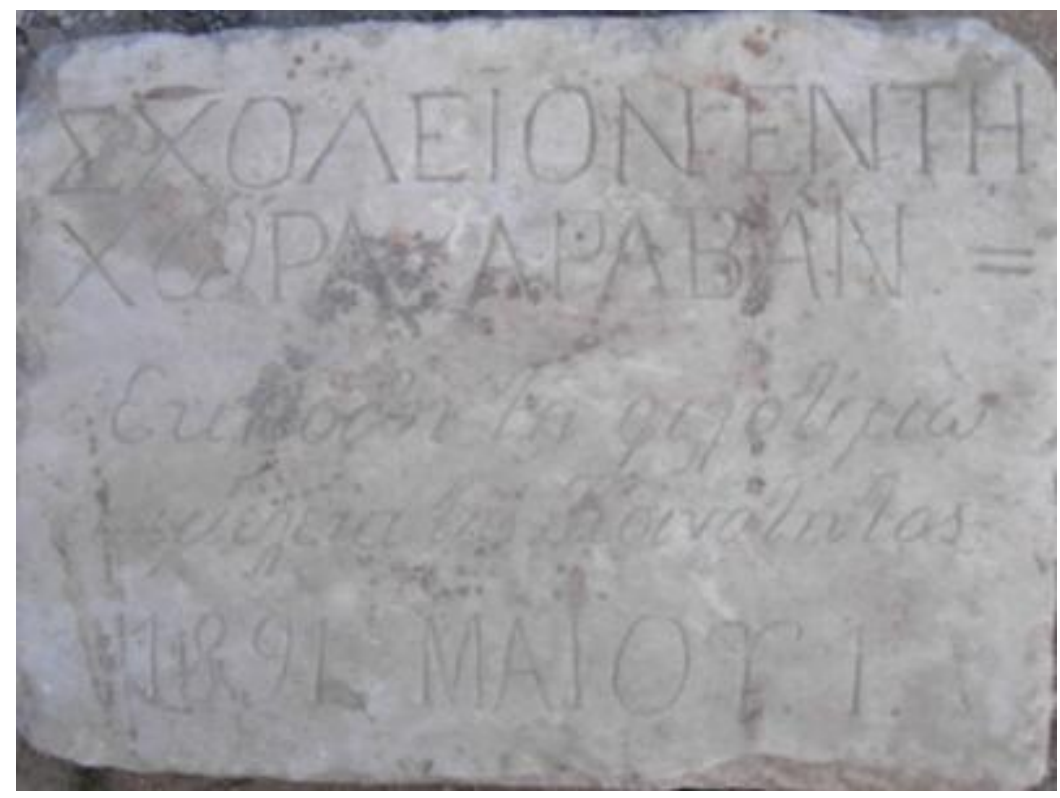

Kaynak: Fotoğraf, Gülen Göktürk

“Kayseriye'nin merkez mektepleri menfaatine olarak Beyoğlu'nda Tepebaşı'nda millet bahçesi tiyatrosunda Lekacas takımı marifeti ile Venedik Bezirganı nam drama ile Avukat’ın Gülünçlü Halleri nam komodianın tasviri Pazar günü gündüzün saat yediden başlayarak icra olunacaktır." ${ }^{18}$

\footnotetext{
${ }^{16}$ Anatoli, 15 Ocak 1892: 4284.

${ }^{17}$ Anatoli, 11 Şubat 1891: 4295.

${ }^{18}$ Anatoli, 19 Ocak 1891: 4286.
} 
"Konya Eparhiasına (vilayetine) tabi Gelveri (Güzelyurt) kariyesinin Rum mektepleri menfaatine olarak gelecek Pazar gecesi Şehzadebaşı'nda 'Hayalhane-i Osmani' Theatrosu'nda (tiyatrosunda) 'Namuslu Familyaya iftira' nam drama ile kanto ve baletler (bale gösterileri) icra olunacaktır." 19

Bu ilanlara gazetenin hemen hemen her nüshasında rastlamak mümkündür. Davetin yapıldığı nüshanın akabindeki bir sayıda da gösterilerin nasıl geçtiğine, kimlerin katıldığına, ne kadar hasılat elde edildiği gibi konulara dair notlar ve bazen de eleştiriler yayınlanmıştır:

“Aravan (Kumluca) kariyesinin mektepleri menfaatine olarak İstanbul'da Osmanlı theatrosunda (tiyatrosunda) geçen Pazar akşamı Minakyan Efendi'nin Kumpanyası marifeti ile icra olunan parastasis (gösteriler) mükemmel surette idi. 'Paris'te Misk Sokağı'nda Vaka' nam dramayı Minakyan Efendi ile Madam Azvik ve Aleksanyan Efendi güzelce tasvir etmişlerdir. Seyirciler alkışlayıp, dramanın sonunda rıfatlı Hristaki Efendi Zampoğlu tarafından Minakyan Efendi ve Aznik Hanım'a birer demet çiçek verilmiştir." 20

Dönemin bütün etkinliklerde olduğu gibi Anadolu mektepleri için düzenlenen gösterilerde Marş-ı Hamidi çalınmış, seyirci ayağa kalkarak iştirak etmiş ve zaman zaman da "Padişahım çok yaşa" duasını etmişlerdir. Kayseriye mektepleri yararına düzenlenen etkinliğin nasıl geçtiği Anatoli'nin bir sonraki sayısında aşağıdaki gibi anlatılmıştır:

“Evvelki Pazar günü gündüzün Beyoğlu’nda Tepebaşı Millet Bahçesi'nin tiyatrosunda Lekacas takımı marifeti ile Kayseriye'nin merkez mektepleri menfaatine olarak tertip olunan parastasis icra olunup...Serasker Zafer Peyker'in mahdumu saadetlü Sadi Paşa, Aydın vilayeti defterdar-ı sabıkı saadetlü Kadri Beyefendi ve bilhassa memleket ve vatanımız muteberanından bir hayr-ı zevat-ı muhtereme ve familyalar hazır bulunmuştur... Bu panayır-ı vatanın başlangıcında ve sonunda musiki takımı marş-ı Hamidi'yi icra edip, umum ayağa kalkarak, vacibe-i ihtiram ve taazim-i ifa ve hitamında sürekli surette el çırparak iştirak etmişlerdir. Mezkur parastasisin biletlerinden yüzde sekseni hemşehrilerimize ve bir kısm-ı cüzzisi hemşehrilerimiz olmayıp, ikide birde mektepleri ve sair hayrathaneleri için bize müracaat edenlere tevzi olunduğu halde, kendisine bilet göderilen bir zatın ağzından 'uf, başımıza bir de Kayseriye mektebi mi çıktı?' sözünü işittiğimizden derinimizde pek müessir bir esef hissettik...Memleketimize mahsus olan teşebbüsatımız için velev-en-şevk ile dostumuz bildiğimiz Kapadokyalı olmayana müracaat etmemeliyiz. Mamafih, haricen bize müracaat olundukça 'uf, püf' demeyerek kemal-i sehavetle isbat-ı mürüvvet etmeliyiz." ${ }^{21}$

Kısacası hemşehrimiz yani Kapadokyalı olmayan, "uf, puf" diyecek olan gelmesin uyarısının arkasında cemiyetlerin, destekledikleri okulların menfaatine tertipledikleri etkinliklere verdikleri değer anlaşılmaktadır. Zira sılada kalanlar eğitilmeyi beklemektedir ve bu uğurda hiç bir ciddiyetsizliğe tahammül edilmemektedir. Yine eğitimin önemine dair bir makalede aşağıdaki uyarı yapılmakta ve yabancılar tarafından ezilmemek için cahil kalmamanın ne kadar elzem olduğu vurgulanmaktadır:

${ }^{19}$ Anatoli, 7 Şubat 1891: 4293.

${ }^{20}$ Anatoli, 1 Şubat 1891: 4291.

${ }^{21}$ Anatoli, 22 Ocak 1891: 4287. 
“Gözümüzü açalım. Bundan böyle biz bize kalmıyoruz...Anadolumuzda demir yollar(ı) yapılıyor. Geçim için ta Amerika'da(n) memleketimize ademler gelecektir. Cahil kalır isek hizmetçilikten başka işe yaramayacağız."22

Aydınlatmayı görev edinen Anatoli yer yer yabancı gazete ve dergilerden çevirilere de yer vermiştir. Çocuk eğitimi ve aile hayatına verilen önem oldukça açıktır. Gelin kaynana ilişkisine dair bir makalede gelin ile kaynana arasında çıkabilecek sorunların sebepleri ele alınmış ve bu ikilinin ilişkilerinin muhabbete nasıl nail olacağı aktarılmıştır. ${ }^{23}$ Yine başka bir nüshada, Ürgüplü Deliavramidis erkek çocuklarının aileleri tarafından küçük yaşlarda gurbete para kazanmaya veya tahsil için gönderilmelerini eleştirmektedir. Yazara göre, henüz olgunlaşmadan gurbete giden çocuklar kötü alışkanlıklara sapmaya meyilli olurlar ve ne ailelerine ne de vatanlarına bir hayırları dokunur.

“Atalar evlatlarını gurbete göderirler. Maksatları ya kendilerine bir faide hasıl olmak veyahud terbiye ile medeniyete vakıf etmek içindir. Halbuki aksi zuhur ediyor...Maksadın aksi zuhur etmesinde bazı ataların vezifesini bilmemeleri sebep oluyor...Maksadın birinci cihetini teftiş edelim. Henüz 10-12 yaşında nev nihal çocuklar bir dükkana hizmetçi ve çırak veriliyor. Bu çocuğun şunun bunun ve hatta dükkandakilerin ağzından çıkan bi-edebane sözleri işitmekten çirkin muamelelerini görmekten ve bed ahlak olmaktan başka kendilerine ve atalarına ne faidesi olabilir. Ikinci cihetine gelelim. Çocuk tahsili için 10-12 yaşında gurbete gönderiliyor. Ahlakı, adabı, başka bir memleketi görüyor...Yeni yeni huylara tesadüf ediyor ve böylelikle tahsile ilm-ü marifet edeceğine çoğu bed huy, bed ahlak, hafif meşrep, atalarını, vatanlarını beğenmez oluyorlar... Çocuklar sinleri kendilerini koruyabilecek dereceye varıncaya değin kendi memleketlerinde atalarının ve hiç olmaz ise analarının nezareti tahtında tahsili ilm etmelidirler. Badehu gurbete gidebilirler."24

Deliavramidis'in, gurbete gidilmemesi taraftarı olmadığı şüphesizdir. Ona göre, çocuklar manevi değerleri aile hayatında öğrendikten ve belli bir olgunluğa eriştikten sonra eğitim veya çaışmak için gurbete gitmelilerdir. Buradan Anatoli'nin bir taraftan Anadolulu Hıristiyanları aydınlatmayı hedeflediği ve mümkün oldukça her tür eğitim faaliyetine destek olduğu ancak bir taraftan da mevcut değerlerin muhafaza edilmesinden yana bir tutum takındığı anlaşılmaktadır. Din ve Anadolu'ya özgü ahlaki değerler Anatoli için büyük bir önem arz etmiştir.

\footnotetext{
${ }^{22}$ Anatoli, 12 Şubat 1891: 4295.

${ }^{23}$ Anatoli, 12 Şubat 1891: 4295.

${ }^{24}$ Anatoli, 22 Ocak 1891: 4287.
} 
Şekil 3: Vücudun Bölümleri, Anatoli, 27 Noemvrios (Kasım) 1851. Gazete bilim ve tıp alanlarında da okuyucusunu bilgilendirirdi.

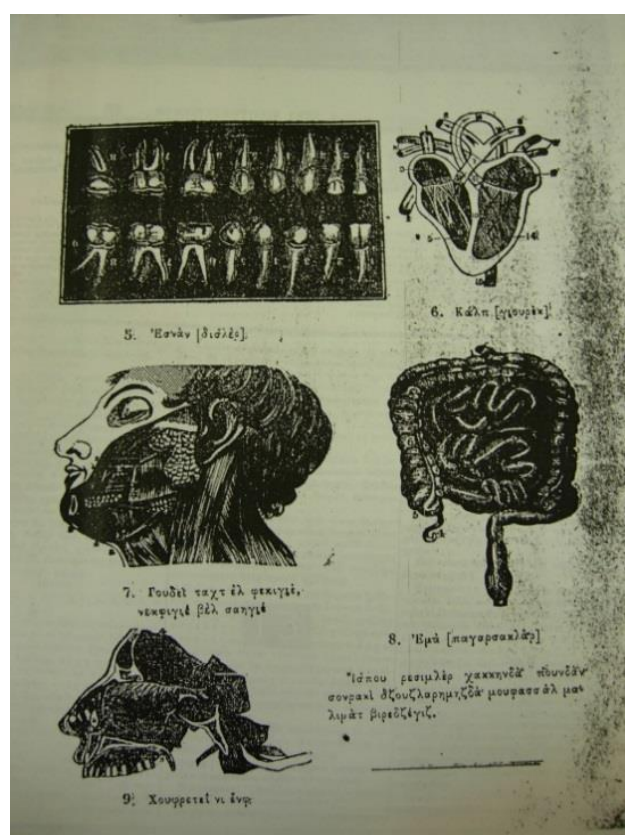

\section{Sonuç}

Anadolu Rumları, özellikle ondokuzuncu yüzyılın ikinci yarısından itibaren Osmanlı nüfusu içerisinde zengin bir kültürel hayata sahiplerdir. Önde gelenleri yine bu dönemde kendilerince "aydınlanmayı" dert etmişlerdir. Aydınlanma ile kastedilen kendi kültürel, dini ve dilsel değerlerini muhafaza ederken çağın gerekliliklerine ayak uydurmayı, eğitim almayı, dünyadaki gelişmeleri takip etmeyi kapsamıştır. Ayrıca misyonerler karşısında dinlerini muhafaza etmeyi ve daha iyi anlamayı da içermiştir. Özellikle Osmanlı́nın bu son döneminde, liman kentlerinin dünya ticaretine açılmasıyla göç çekici bir kuvvet halini almış, pek çok Anadolu Hıristiyanı büyük kentlere göç etmeye başlamıştır. Aydınlanma sorunun farkedilmesi göç olgusuyla ilintilidir. Göç ettikleri büyük şehirlerde kendi durumlarını, Rum cemaatinin diğer unsurları ve Yunan milliyetçiliğinin kültürel yayılmacılığı etkisinde sorgulamaları sonucunda bir kimlik sorunsalı ortaya çıkmıştır. Zaman zaman kendilerini yerli Rumlara kabul ettirebilmek, aşağılanma ile baş edebilmek ve sılayı alt yapıdan eğitime kadar desteklemek için hemşehri cemiyetleri kurmuşlardır. Tüm bunlar sahiden bir aydınlanma hareketi ortaya çıkartmıştır. Okullarına maddi destek sağlayabilmek için İstanbul'da gösteri ve tiyatro etkinlikleri düzenlemişlerdir. İstanbul'daki cemaatin mensuplarının ve diğer nüfuzlu kişilerin katılımından elde edilen hasılat sıladaki mektepler için harcanmıştır. Aydınlanma sürecine yayınlarıyla destek veren Anatoli gazetesi de gösterilerin davetiyelerini ve gösterilerle ilgili haberleri yayınlamıştır. Anatoli az gibi görünen tirajına rağmen ciddi bir okur kitlesine sahiptir. Buradan hareketle kendisine bir misyon edinmiş ve siyasi konularda görece tarafsız ya da sessiz bir tutum sergilerken, eğitime ve ahlaki değerlere büyük destek vererek yayın hayatına altmış bir yıl (bazı tarihçilere göre 71) yıl devam etmiştir. Anatoli gazetesinin Anadolu Ortodoksu'nun sesi olduğunu iddia etmek yerinde olacaktır. 


\section{Eskişehir Osmangazi Üniversitesi ïiBF Dergisi}

\section{Kaynaklar}

Agios Yorgos: Aravan Kariyesi'nin İstanbul'daki Kardeşlik Cemiyeti, İstanbul: Patrikhane Matbaası, 1905.

Anatoli (Şark) Gazetesi, 27 Kasım 1851.

Anatoli (Şark) Gazetesi, 1891-1899.

Alexandris, Alexis, (1999), "The Greek Census of Anatolia and Thrace (1910-1912): A Contribution to Ottoman Historical Demography", (Eds. Dimitri Gondicas and Charles Issawi), Ottoman Greeks in the Age of Nationalism: Politics, Economy and Society in the Nineteenth Century, Princeton: Darwin Press.

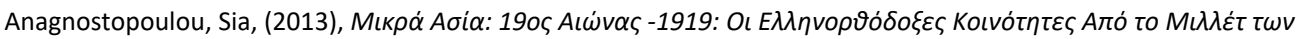

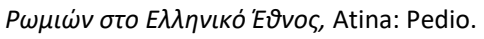

Anzerlioğlu, Yonca, (2009), Karamanlı Ortodoks Türkler, Ankara: Phoenix Yayınevi.

Augustinos, Gerasimos, (1997), Küçük Asya Rumları, Ankara: Ayraç Yayınları.

Balta, Evangelia, (2003), “Gerçi Rum isek de Rumca Bilmez Türkçe Söyleriz: The Adventure of an Identity in the Triptych: Vatan, Religion and Language”, Türk Kültürü Incelemeleri Dergisi, 8, 25-44.

Baykurt, Cami, (2007), Hıristiyan Türkler, İstanbul: Karma Kitaplar.

Benlisoy, Foti ve Benlisoy, Stefoi, (2016), Türk Milliyetçiliğinde Katedilmemiş Bir Yol: Hıristiyan Türkler ve Papa Eftim, İstanbul: İstos Yayın.

Benlisoy, Foti ve Benlisoy, Stefo, (2000), “19. Yüzyılda Karamanlılar ve Eğitim: Nevşehir mektepleri”, Toplumsal Tarih, 74, 24-33.

Benlisoy, Foti ve Benlisoy, Stefo, (2010), "Karamanlılar”, “Anadolu Ahalisi” ve “Aşağı Tabakalar”: Türkdilli Anadolu Ortodokslarında Kimlik Algısı", Tarih ve Toplum Yeni Yaklaşımlar, 11, 7-22.

Benlisoy, Stefo, (2003), “istanbul’da Yaşayan Nevşehirli Ortodokslar Tarafından Kurulan Papa Yeorgios nam Cemiyet-i Islahiyyesi", Tarih ve Toplum, 236, 35-41.

Clogg, Richard, (1982), "The Greek Millet in the Ottoman Empire", (Eds. Benjamin Braude and Bernard Lewis), Christians and Jews in the Ottoman Empire: The Functioning of a Plural Society (vol. 1), New York: Holmes \& Meier Publishers.

Clogg, Richard, (1996), "Some Karamanlidika Inscriptions from the Monastery of the Zoodokhos Pigi, Balıklı, Istanbul”, Anatolica: Studies in the Greek East in the 18th and 19th Centuries, Hampshire; Vermont: Variorum, 55-67.

Dawkins, M. Richard, (1916), Modern Greek in Asia Minor: A Study of the Dialects of Silli, Cappadocia and Pharasa with Grammer, Texts, Translations and Glossary, Cambridge at the University Press.

Der-i Saadette Vaki Gelveri'nin Maarifperver Nazianzos Nam Uhuvetinin Nizamnamesi Tesisi, 1884.

Ekincikli, Mustafa, (1998), Türk Ortodoksları, Ankara: Siyasal Kitapevi.

Ergene, Teoman, (1951), İstiklal Harbinde Türk Ortodoksları, İstanbul: i. P. Neşriyat Servisi.

Erol, Merih, (2004), “Evangelinos Misailidis”, Toplumsal Tarih, 128, 70-71.

Göktürk, Gülen, (2015), Well-preserved Boundaries: Faith and Co-existence in the Late Ottoman Empire, Yayınlanmamış Doktora Tezi, Ankara: Orta Doğu Teknik Üniversitesi.

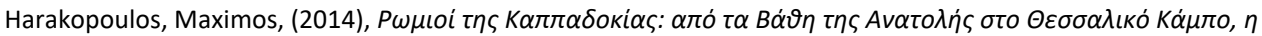

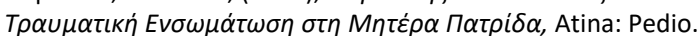

Şimşek, Ş. Şehnaz, (2010), "The Anatoli Newspaper and the Heyday of the Karamanlı Press", (Eds. Evangelia Balta \& Mattias Kappler), Cries and Whispers in Karamanlidika Books, Wiesbaden: Harrassowitz Verlag, 109-124.

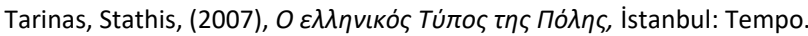

Vassiadis, George, (2007), The Syllogos Movement of Constantinople and Ottoman Greek Education 1861-1923, Athens: Center for Asia Minor Studies.

Vryonis, Spyros, (1971), The Decline of Medieval Hellenism in Asia Minor and the Process of Islamization from the Eleventh through the Fifteenth Century, Berkeley: University of California Press. 